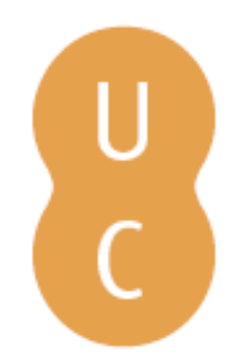

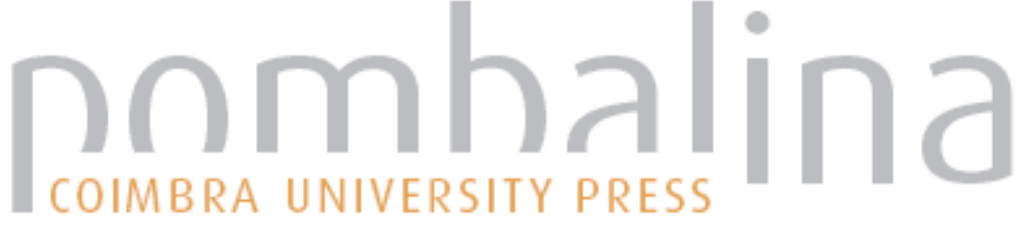

\section{A República de António Maria de Azevedo Machado Santos (1875-1921)}

Autor(es): $\quad$ Silva, Armando Malheiro da; Cordeiro, Carlos; Torgal, Luís Filipe Reis

Publicado por: Imprensa da Universidade de Coimbra

URL

persistente: URI:http://hdl.handle.net/10316.2/31151

DOI: $\quad$ DOI:http://dx.doi.org/10.14195/978-989-26-0497-8_17

Accessed : $\quad$ 26-Apr-2023 14:02:04

A navegação consulta e descarregamento dos títulos inseridos nas Bibliotecas Digitais UC Digitalis, UC Pombalina e UC Impactum, pressupõem a aceitação plena e sem reservas dos Termos e Condições de Uso destas Bibliotecas Digitais, disponíveis em https://digitalis.uc.pt/pt-pt/termos.

Conforme exposto nos referidos Termos e Condições de Uso, o descarregamento de títulos de acesso restrito requer uma licença válida de autorização devendo o utilizador aceder ao(s) documento(s) a partir de um endereço de IP da instituição detentora da supramencionada licença.

Ao utilizador é apenas permitido o descarregamento para uso pessoal, pelo que o emprego do(s) título(s) descarregado(s) para outro fim, designadamente comercial, carece de autorização do respetivo autor ou editor da obra.

Na medida em que todas as obras da UC Digitalis se encontram protegidas pelo Código do Direito de Autor e Direitos Conexos e demais legislação aplicável, toda a cópia, parcial ou total, deste documento, nos casos em que é legalmente admitida, deverá conter ou fazer-se acompanhar por este aviso. 
Armando Malheiro da Silva

Maria Luiza Tucci Carneiro

Stefano Salmi

Coordenação

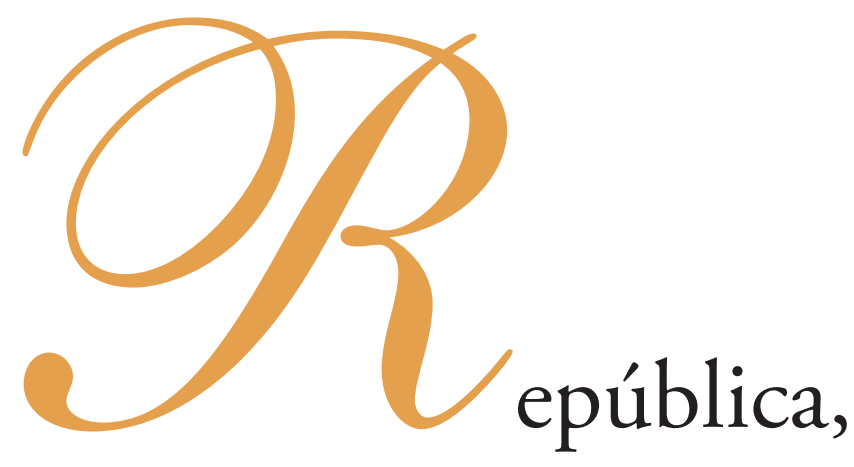

Republicanismo

e Republicanos

Brasil • Portugal • Itália 


\author{
Armando Malheiro da Silva \\ Carlos Cordeiro \\ Luís Filipe Reis Torgal
}

\title{
A REPÚBLICA DE ANTÓNIO MARIA DE AZEVEDO MACHADO SANTOS (1875-1921)
}

Compreender a I República Portuguesa e os seus paladinos...

Em 2010 será comemorado o centenário da implantação da República em Portugal. Movimentam-se já diversas instituições, quer científicas, quer políticas, no sentido de conferirem às comemorações uma expressão significativa, esperando-se que sirvam para o aprofundamento da investigação científica sobre tão complexa conjuntura da História de Portugal e também, para uma correcta pedagogia dos valores democráticos.

Entretanto, vão-se acumulando nas estantes e nos escaparates das livrarias vários ensaios historiográficos — de história política, religiosa, cultural e económico-social - que reformulam antigas representações mais simplificadoras, quando não panegíricas ou diabolizadoras da I República. Afinal, tal como toda a realidade histórica, essa época terá sido bem mais complexa e, por isso, não pode reduzir-se a clichés intangíveis que reflectem, em demasia, as vivências políticas e/ou as convicções ideológicas dos sujeitos que os construíram. Trata-se, aliás, de uma temática que foi tabu nas licenciaturas de História e nas propostas de doutoramento durante o Estado Novo, só tendo entrado na agenda historiográfica após o 25 de Abril de 1974, sem que, em muitos casos, se tenha perdido 
a carga ideológica inerente aos respectivos narradores/historiadores. Desde a década de 60 tornou-se evidente, entre jovens investigadores no exílio, a influência do materialismo histórico. Esta matriz inspirou o exponencial interesse pelo estudo da I República já em pleno Portugal democrático, originando interpretações diferentes. Umas mais próximas da linha revalorizadora (reforço da via democrática e respeito pelos princípios "liberais" do Estado Moderno) do demoliberalismo consubstanciado no vintismo e retomado no último quartel de Oitocentos, através do movimento republicano ajustado a uma conjuntura de titubeante e contraditório capitalismo (destaque para Joel Serrão ${ }^{580}$ e Miriam Halpern Pereira ${ }^{511}$; outras fechadas num reducionismo marxista. Por fim, uma linha, de início muito minoritária, despoletada pelo livro de Vasco Pulido Valente A Revolução e o Povo ${ }^{582}$, que apresenta a República de 1910 como um regime revolucionário e violento, baseado na força propulsora de um partido de vanguarda - o Partido Republicano Português — que se propôs, logo após o 5 de Outubro, governar em ditadura e, apesar da fragmentação ocorrida em 1911, os seus principais líderes e mentores nunca deixaram de evocar e de sonhar com uma unidade republicana capaz de regenerar o velho e atrasado Portugal. Uma unidade frágil e, com o passar do tempo, impossível...

Entre uma República excludente, feita só para republicanos e posta sob o estandarte do jacobinismo democrático de Afonso Costa e dos seus sequazes, e uma República "conservadora”, ou seja, aberta a católicos e a monárquicos, houve tensões e reviravoltas desgastantes que contaram com a participação, até ao momento da sua morte brutal em 1921, do "Triunfador que com o povo e os seus brilhantes companheiros de armas, de mar e terra, tinham liquidado a monarquia":

"Exausto, quase sem forças, de voz sumida, entrega o comando superior a general Carvalhal, e pede que se vá à Câmara proclamar a República e nomear o governo. O soldado abatia a espada perante o poder civil. E quan-

\footnotetext{
${ }^{580}$ SERRÃO, Joel - Liberalismo, socialismo, republicanismo: antologia de pensamento politico português. Lisboa: Livros Horizonte, 1979, $2^{\text {a }}$ ed. ; e ainda Idem - Da "Regeneração" à república. Lisboa: Livros Horizonte, 1990. p. 119-143.

${ }^{581}$ PEREIRA, Miriam Halpern - Das Revoluções liberais ao estado novo. Lisboa: Editorial Presença, 1993.

582 VALENTE, Vasco Pulido - O Poder e o povo: a revolução de 1910. Lisboa: Publicações Dom Quixote, 1976.
} 
do os ministros the chamaram Almirante, ele, com honrada e sincera modéstia, declinou noutros bravos a glória da empresa, falando apenas na Assembleia Constituinte" ${ }^{\prime 583}$.

Machado Santos, perante essas Repúblicas em confronto, parece ter abraçado as duas, considerando-se, nas páginas do seu jornal Intransigente, zeloso guardião da República sonhada (e de contornos algo fluidos) no seio da gestação carbonária da revolta e, ao mesmo tempo, posicionando-se contra a hegemonia dos afonsistas e eventuais aliados, contra todas e quaisquer medidas políticas e administrativas por eles promulgadas - do anticlericalismo a tudo o mais... Esta postura ambígua colocou-o, a si e ao punhado de indefectíveis que com ele se mantiveram firmes e apegados aos "épicos" momentos da Rotunda, à margem do sistema político instaurado em 1910 e tudo indica, pela análise das convulsões político-militares ocorridas, ter sido um factor de efectiva desestabilização.

Podemos, inclusive - e este ponto constitui a tese nuclear da nossa pesquisa sobre Machado Santos e a "sua" República - postular que a conduta do grupo intransigente, reformista, populista, federalista e anti-afonsista formado em torno do Triunfador deve ser trazida ao debate que, em estudo publicado em 2004, Rui Ramos estimulou, tecendo uma extensa resposta à pergunta: "Foi a Primeira República um regime liberal?" 584 Nas respectivas Conclusões lança algumas "teses" às quais a trajectória e o discurso ideo-político de Machado Santos parecem ajustar-se:

"O regime republicano era um regime revolucionário, entendendo-se por tal a dependência do poder em relação, não a um quadro legal, mas a um movimento revolucionário que se comportava como o factor de um golpe de estado permanente. (...) A República era um regime revolucionário que, não negando alguns dos princípios fundadores da monarquia liberal

583 PIMENTEL, Alberto - As Constituintes de 1911 e os seus deputados. Obra compilada e dirigida por um antigo official da Secretaria do Parlamento. Lisboa: Livraria Ferreira, 1911. p. 228.

${ }^{584}$ RAMOS, Rui - "Foi a primeira república um regime liberal? Para uma caracteriação politico do regime republicano português entre 1910 e 1920". In BAIÔA, Manuel (ed.) - Elites e Poder: a crise do sistema liberal em Portugal e Espanha (1918-1931); Elites y Poder: la crisis del sistema liberal en Portugal y España (1918-1931). Lisboa: Colibri; Centro Interdisciplinar de História, Cultura e Sociedades da Universidade de Évora, 2004, p. 185-246. 
(nomeadamente, a rejeição da tradição da monarquia absoluta católica), negava o tipo de vida politica desenvolvida neste estado e tendencialmente minava as garantias legais dos direitos e a pluralidade política.

Dizer que a República não era uma democracia liberal não significa dizer que o objectivo dos republicanos não era o estabelecimento de uma democracia liberal. A maior parte deles nunca teve, de facto, outro projecto: não eram fascistas, nem comunistas, como alguns dos seus inimigos os classificaram em momentos azedos de polémica. Mas o revolucionarismo da República impediu a transição para uma forma daquele tipo de democracia liberal na Europa ocidental do pós-guerra. Impediu-a também de oferecer, na continuação do modus vivendi político estabelecido dentro da monarquia constitucional, um quadro para o alinhamento dos líderes e grupos políticos dispostos a coabitar dentro de um estado constitucional-pluralista, empurrando uma parte deles - à esquerda e à direita - para a conspiração contra o dominante"

Para o mesmo debate há, em torno da questão do reformismo autoritário que emerge, em especial, durante a primeira fase da I República, entre 1910 e 1919, uma leitura complementar que foi já formulada e é oportuno lembrá-la aqui.

Os ingredientes doutrinários, os novos elementos ideológicos do final de Oitocentos e os aspectos contraditórios da conjuntura datada entre 1890 e 1926, com destaque para uma grave crise financeira que coexistiu com índices demográficos e económicos comprovativos de um inegável crescimento no Portugal finissecular ${ }^{586}$, propiciaram a génese e a evolução de um dilema crucial para os republicanos portugueses (demasiado influenciados, porém, pelo modelo republicano francês da III República para que se pudessem aperceber completamente dos sérios riscos que o mesmo comportava para o futuro). E o dilema era este: o esquema representativo baseado no predomínio da Câmara dos Deputados estava em consonância com o princípio da representação da Nação através dos

${ }^{585}$ Ibidem, p. 245.

${ }^{586}$ Ver MATOS, Sérgio Campos - "Da Crise da Monarquia Constitucional à Primeira República em Portugal (1890-1910)". In España-Portugal. Estúdios de Historiografia Contemporânea. Dir. Hipólito de la Torre Gómez e António Pedro Vicente. Madrid: Ed. Complutense, 1998, p. 51-64. Ver ainda Crises em Portugal nos séculos XIX e XX. Actas do Seminário organizado pelo Centro de História da Universidade de Lisboa, 6 e 7 de Dezembro de 2003. Coordenação de Sérgio Campos Matos. Lisboa: Centro de História da Universidade de Lisboa, 2002. 
seus eleitos, mas enfraquecia o Executivo, debilitava a capacidade de manobra dos Governos. Ora, quanto mais fracos fossem os Governos menos concretizável seria a transformação enérgica e progressista do velho Portugal num País novo e revigorado. A República - acreditavam os republicanos "históricos" — não se fizera para ser apenas um prolongamento do modelo já vigente sob a Monarquia Constitucional, um regime decadente e anacrónico, contrário aos desafios do futuro. A República trazia, em si, uma esperança prometeica muito forte e diferente...

A missão republicana fundadora de um Portugal novo (mais do que renovado) exigia, desde logo, a unidade dos republicanos e a presença de um Partido Republicano frentista e mobilizador das energias nacionais num quadro constitucional omisso quanto à consagração institucional dos partidos (será preciso esperar pela Constituição da República de Weimar, a partir de 1918, para que se institua o Estado de Partidos). A função do PRP era revolucionária no sentido em que lhe cabia derrubar um regime e substituí-lo por outro substancialmente diverso, capaz de moralizar, de educar e de fazer progredir economicamente todo o País. Além disso, assumiu-se como uma espécie de "locomotiva" ou partido-vanguarda que se propunha republicanizar toda a sociedade contra a vontade de monárquicos, católicos e da Igreja Católica enquanto instituição acusada de contribuir, através do controle do sector educativo e da consciência religiosa dos cidadãos, para o atraso obscurantista de todo um Povo, que tardava em libertar-se das grilhetas da opressão nobiliárquico-clerical.

No entanto, essa missão vanguardista e revolucionária começou a fracassar e a ser transfigurada logo em finais de 1911, após a aprovação da Constituição com a fragmentação do PRP em três grupos que até 1917 haveriam de disputar entre si o poder. Sobressaiu um deles, por ser o único que deteve a rede sócio-política e o aparelho organizativo criado antes de 5 de Outubro. Referimo-nos, obviamente, ao velho PRP dominado por Afonso Costa e seus sequazes, conhecido também pela designação oficiosa de Partido Democrático, ao qual se opuseram António José de Almeida e seus amigos evolucionistas (Partido Republicano Evolucionista) e Brito Camacho, líder da União Republicana ${ }^{587}$. É forçoso realçar

\footnotetext{
587 Ver sobre os programas destes e de outros partidos após a implantação da República MARQUES, A. H. de Oliveira - História da $1^{a}$ República Portuguesa: as estruturas de base. S.1.: Iniciativas Editoriais, s.d., p. 534-589. E ainda LEAL, Ernesto Castro - "Partidos e grupos políticos na I República”. In História de Portugal dos tempo pré-bistóricos aos nossos dias. Dir. João
} 
a dissidência machadista, depositária de um ideal republicano revolucionário e confuso, "intransigente" e frontalmente anti-afonsista: o "herói da Rotunda", Machado Santos, e seus amigos - entre outros o camarada de armas, também da Marinha, Carlos da Maia (ambos assassinados conjuntamente com António Granjo em 19 de Outubro de 1921) e Francisco Cunha Leal, com acentuado protagonismo politico-partidário após 1918 - haveriam de acusar Afonso Costa, António José de Almeida e Brito Camacho de aviltarem ou "prostituírem" a República que militares e civis carbonários haviam conseguido concretizar, vencendo descrenças e poderosos receios. Os machadistas reclamavam-se do genuíno e fecundo legado de um sonho ou da "Aurora Ideal" tão ardentemente almejada, conservando-se sempre em rebelião mais ou menos activa e constante contra o que Marcelo Rebelo de Sousa classificou de "multipartidarismo imperfeito ou de partido dominante" (o PRP-PD), agravado, após 1919, por uma instável e confusa pulverização partidária.

A quebra de unidade republicana enfraqueceu e, em larga medida, interrompeu a obra "ditatorial" ou autoritária do Governo Provisório, caracterizada por um pacote legislativo reformista e confrontativo, como sucedeu com a famosa "intangível" - a Lei da Separação das Igrejas do Estado promulgada pelo Ministro da Justiça e dos Cultos, Afonso Costa, e defendida até 1918 como uma das principais "pedras de toque" da ideologia e da acção política republicana.

Em síntese, sublinha-se a proposta interpretativa que vai no sentido de reconhecer que o tronco doutrinário e ideológico, cultural e social, em que se filia o republicanismo português lhe conferiu, em crescendo, uma vocação autoritária e intransigente (intransigência moral e política) indispensável à obra de regeneração nacional que inflamou a geração activa de 90. Uma vocação não assumida consensualmente, mas patente na prática republicana de 1910 a 1926 sob duas formas ou modalidades, ambas se reclamando de um reformismo político, social e económico tendo em vista o aprofundamento democrático pelo reforço autoritário do executivo: um autoritarismo dissimulado e contraditório no plano político-institucional (submetido aparentemente ao figurino parlamentarista, tendo sido esta, de facto, a táctica constante dos afonsistas, secundada

Medina. Amadora: Ediclube, Edição e Promoção do Livro, Lda, 1993, vol. 10 - A República - I. p. 287-318. 
no essencial por almeidistas e camachistas); e um presidencialismo autoritário declaradamente ordeiro ${ }^{588}$.

Sem uma interpretação global, expressa como hipótese que a análise monográfica e sistemática tende a ir confirmando, não faria sentido incidir especificamente sobre uma figura e seu papel histórico, quando ela se entrelaça e embrenha na teia conjuntural complexa de um País periférico numa Europa e num Mundo ocidental em transformação no âmbito, do que Eric Hobsbawm designou por Era do Império, 1875-1918.

Neste estudo exploratório, que antecede uma abordagem de maior fôlego sobre Machado Santos, decidimos focar, apenas, a génese e a emergência do Herói da Rotunda e do emaranhado de circunstâncias que marcaram a sua consagração como artífice maior do Portugal republicano, deixando para essa posterior abordagem a relação tumultuada e trágica que ele manteve com o regime que ajudara a instaurar.

Para um retrato humano do Triunfador

Do punho do próprio terá saído a notícia biográfica ou curricular, que se estende por cinco páginas, entregue a Alberto Pimentel, compilador oculto do "quem é quem" dos primeiros parlamentares constituintes da República. O texto contém umas brevíssimas notas pessoais e de carreira, inflectindo, depois, no relato dos trabalhos preparatórios do movimento revolucionário que viria a consumar-se, com êxito, em 5 de Outubro de 1910.

Dessa notícia biográfica coeva sobressai

"António Maria de Azevedo Machado Santos

Deputado pelo Círculo $n^{\circ} 35$ Lisboa (Ocidental)

Oficial da Administração Naval. 36 anos de idade. Nasceu em Lisboa a 10 de Janeiro de 1875. Filho de Maurício Paulo Victoria dos Santos e de D. Maria

\footnotetext{
${ }^{588}$ SILVA, Armando Malheiro da - "A República e o reformismo democrático autoritário (1890-1926): uma proposta interpretativa”. In Portugal-Brasil: uma visão interdisciplinar do século xx: actas do Colóquio 2 a 5 de Abril de 2003. Coord. Maria Manuela Tavares Ribeiro. Coimbra: Centro de Estudos Interdisciplinares do Século xx da Universidade de Coimbra - CEIS 20; Quarteto Editora, 2003. p. 21-62.
} 
d'Assumpção Azevedo Machado Santos. Alistou-se em 29 de Outubro de 1891. Promovido a aspirante de $2 .^{a}$ classe em 1892, a comissário naval de 3. ${ }^{a}$ classe em 1895, a comissário naval de 2. ${ }^{a}$ classe em 1911. Tem as medalhas de prata de comportamento exemplar e a de campanhas no Ultramar. (...)

Num extenso relatório, que corre impresso, Machado Santos é director e proprietário do jornal O Intransigente. Tendo-se este deputado, em uma das sessões das Constituintes, declarado chefe da carbonária portuguesa, Luz d'Almeida, ausente dessa assembleia contestou tal chefia declarando ser ele, $e$ não Machado Santos, quem ocupa tal lugar, acrescentando que tão depressa chegasse a Lisboa, se demitiria"s89.

Na Parte V da mesma obra surgem reunidos os Projectos de Constituição, o Parecer da Comissão de Constituição e o texto final da Constituição Política da República Portuguesa (1911). Entre os projectos apresentados, o segundo é o de autoria do deputado Machado Santos e entregue à Assembleia Nacional Constituinte, na sessão de 23 de Julho de 1911, com sete capítulos e 36 artigos, sem reprodução do articulado - que certamente aproveitou para a proposta constitucional apresentada no livro A Ordem Pública e o 14 de Maio, mais precisamente no Projecto de Estatuto Nacional aí incluído ${ }^{590}$.

Mas estas notas são já e sobretudo sobre o perfil político do biografado, convindo, aqui e de imediato, regressar ao registo pessoal para que descortinemos o espaço onde cresceu e se formou, o que na sua trajectória de marinheiro de guerra o marcou em todas as dimensões e o essencial da sua postura já dento da República que ajudou a instaurar.

António Maria de Azevedo Machado Santos, nasceu a 10 de Janeiro de 1875 na velha rua da Inveja, entre a Mouraria e o Campo de Sant'Ana, no centro da "grande alface de mármore e de granito que é esta nossa Lisboa" precisamente na freguesia de Nossa Senhora da Pena, designada originariamente

${ }^{589}$ PIMENTEL, Alberto - As Constituintes de 1911 e os seus deputados, op. cit., p. 225-227.

590 SANTOS, Machado - A Ordem publica e o 14 de Maio. Lisboa: Papelaria e Tipografia Liberty, 1916, p. 104-116.

${ }^{591}$ MADUREIRA, Joaquim - Caras Lavadas. Machado Santos. Lisboa: Lamas e Franklin Editores, 1911, p. 7. 
Sant'Ana. Filho de Maurício Paulo Victoria dos Santos, empregado de comércio ${ }^{592}$, e de D. Maria da Assunção Azevedo Machado dos Santos ${ }^{593}$.

Aos 16 anos de idade assentou praça na Marinha, em 29 de Outubro de 1891, ano do célebre ultimato inglês que convulsionou a opinião pública portuguesa. Frequentou a Escola Naval de 20 de Outubro de 1891 a 23 de Julho de 1892, passando no dia seguinte para a Administração Naval. Ingressado no efectivo da Armada, a 5 de Janeiro de 1895, sendo afecto, de 15 de Junho a 27 de Novembro desse ano, ao $2^{\circ}$ Depósito do Arsenal da Marinha.

Dois anos depois, a 29 de Julho de 1899, casou com D. Beatriz Estefânia de Oliveira. Deste matrimónio houve um único filho, nascido a 26 de Março de 1900, de seu nome completo Augusto Zeferino de Azevedo Machado Santos. E é interessante notar que entre Maio de 1899 e Junho de 1900, período que abrange o seu casamento, ficou em terra, desempenhando funções na $4^{a}$ Repartição da Direcção-Geral da Marinha e de Subchefe da Secção de Contabilidade dos Serviços Marítimos do Arsenal.

Entre 1893 e 1895 participou em várias comissões no mar, nomeadamente na canhoneira "Douro" e na corveta "Afonso de Albuquerque", ambas no Tejo. Serviu na mesma corveta em viagem ao Brasil e na corveta "Mindelo" na Estação do Atlântico Sul, destacada no Brasil. Serviu, também, na canhoneira "Rio Lima" rumo à Estação Naval da Índia e fez comissão na fragata "D. Fernando II e Glória”. Toda esta actividade foi desenvolvida enquanto Aspirante de $2^{\text {a }}$ e de $1^{a}$ classes da Administração Naval. A 5 de Janeiro de 1895 seria promovido a Comissário de $3^{\text {a }}$ classe (equivale, hoje, a Guarda-Marinha), posto em que se manteve até 4 de Novembro de 1910. Ascendeu, então, a Comissário de segunda classe (hoje segundo-tenente). Uns meses depois, a 3 de Julho de 1911, receberia nova promoção pela Assembleia Nacional Constituinte (decreto dessa data)

\footnotetext{
${ }^{592}$ Parlamentares e ministros da 1. ${ }^{a}$ república: 1910-1925. Coord. A. H. Oliveira Marques. Paulo Guinote, Pedro Teixeira Mesquita e João Alves Dias. Lisboa: Assembleia da República; Edições Afrontamento, 2000, p. 388. No opúsculo Caras lavadas. Machado Santos é atribuído ao seu pai Maurício uma frase profética que proferira quando lhe foram dizer, no dia 4 de Outubro, quem comandava os revoltosos da Rotunda: Então temo-la tramada, porque quando ele se mete numa coisa leva-a ao fim... Mas é maluco, o meu António, porque ou deixa lá a pele, ou vai servir de degrau aos outros, pensando em todos e esquecendo-se de si (Madureira, Joaquim, Caras lavadas. Machado Santos, op. cit., p. 7-8).

593 Seguimos para a composição desta resenha biográfica os elementos contidos no Processo de Santos, António Maria de Azevedo Machado Santos. Oficial da Armada. Classe — Administração Naval, in Biblioteca Central da Marinha-Arquivo Central.
} 
- desta vez para Capitão-de-Mar-e-Guerra da Administração Naval, contando-se a antiguidade neste posto desde 5 de Julho de 1910 e pelo mesmo decreto foi-lhe concedida a pensão anual vitalícia de $3.000 \$ 000$ réis, livres de quaisquer direitos e impostos. Não voltou a ser mudado de posto até 1917: Contra-Almirante da Administração Naval em 17 de Dezembro e Vice-Almirante da Administração Naval em 7 de Setembro de 1918.

Intercaladas com as comissões no mar, constam do seu processo várias comissões em terra, nomeadamente as que desempenhou antes e logo após ter-se casado. A sua especialidade era a da Administração Naval e é natural a sua passagem pela Majoria General da Armada (como Adido em 1906 e como Adjunto por vários períodos: 1908; 1909; 1911-1915; 1915; 1918), pela Comissão de Compras (1906-1907), pela Administração dos Serviços Fabris (1907-1908) e pela $5^{\mathrm{a}}$ Repartição da Direcção-Geral da Marinha.

No seu processo, sob a rubrica campanhas, ferimentos e feitos de armas, foi anotada a participação no bombardeamento de Antim e Bandim, na Guiné, onde esteve 58 dias de serviço, "considerado de campanha" nos meses de Março a Maio de 1908 (ficaram conhecidas, aliás, como as campanhas de Varela, Cuhar e Bissau). O tirocínio ultramarino, que a partir do último quartel de Oitocentos se tornou constante e inevitável na vida dos militares portugueses quer do exército, quer da Marinha, estendeu-se ainda, no caso de Machado Santos, a Cabo Verde, a Angola, a Moçambique, à Índia e a Macau.

Ainda que, na primeira década e meia da sua carreira militar, tenha demonstrado um comportamento considerado "exemplar" teve qualquer punição disciplinar ou penal nesse período - em 1908, o seu cadastro militar começa a ficar "maculado", pois foi mandado responder, no dia 26 de Junho, em Conselho de Guerra pelo crime de insubordinação (publicara um artigo no jornal O Radical). A 26 de Setembro desse mesmo ano teve de apresentar-se na Majoria General da Armada, com guia da canhoneira "Zambeze", tendo ficado adjunto e preso para Conselho de Guerra, o qual haveria de o julgar a 17 de Outubro. Foi absolvido e restituído ao gozo pleno dos seus direitos.

\footnotetext{
${ }^{594}$ Condecorado com a medalha de prata de comportamento exemplar em 13 de Maio de 1905. Cfr. Ibidem.
} 
Estes actos surgiram na sequência da acção conspirativa e carbonária a que aderiu, a partir de 1907595, e que relata na notícia biográfica entregue a Alberto Pimentel ${ }^{596}$. Estreitou, então, relações com a massa urbana revolucionária, composta por marinheiros, operários, empregados de comércio, boticários, etc., potenciais e efectivos bombistas, agitadores, propagandistas das ideias republicanas, e braços armados, dentro dos quartéis e navios, à ordem de chamada dos seus chefes insurrectos. E em 1909 foi iniciado na loja maçónica Montanha, com o nome simbólico Championnet. Ascendeu, também, à Alta Venda da Carbonária.

A Monarquia Constitucional, instaurada em 1834, agonizava e o republicanismo crescia em adesões e em força, animado por um fortíssimo impulso para a regeneração progressista do nobre povo, nação valente... (versos épicos de A Portuguesa, hino nacional). E Machado Santos ingressou nessas hostes esperançosas, aguerridas e impacientes. Esteve na Rotunda, conseguindo levar os revolucionários à vitória e os Bragança ao exílio...

Instaurada a República e formado o Governo Provisório, Machado Santos regressou à sua condição de oficial da Marinha de Guerra, mas não ficou privado de uma intervenção activa na vida político-institucional. Foi deputado pelo ć́rculo no 35, Lisboa Ocidental, entre 1911 e 1914. E, de início, na Assembleia Nacional Constituinte, quase exclusivamente dominada por republicanos de diferentes poses e sensibilidades, foi agraciado, como atrás se refere, com uma pensão vitalícia e promovido a Capitão-de-Mar-e-Guerra, em sinal de reconhecimento pelo prestimoso e decisivo contributo prestado à República Portuguesa.

595 Ver 1907 no advento da República. Mostra bibliográfica 15 de Março a 9 de Junho. Apresentação Jorge Couto. Coordenação Manuela Rego. Lisboa: Biblioteca Nacional, 2007.

${ }^{596}$ Ver PIMENTEL, Alberto - As Constituintes de 1911 e os seus deputados, op. cit., p. 225-226. É aí escrito que em Agosto de 1907, Machado Santos foi abordado pelo oficial da Armada Serejo para que participasse numa revolta e, mais tarde, Marinha de Campos (desligado, entretanto, do Partido Regenerador Liberal, a cujo líder, João Franco, dirigiu uma carta aberta) e Mascarenhas Inglez procuraram-no com o mesmo objectivo. Terá sido no escritório de Alexandre Braga que Machado Santos conheceu João Chagas e o Almirante Cândido Reis. A revolta de 28 de Janeiro de 1908 ganhou corpo através do impulso organizativo da Carbonária, em que pontificaram Machado Santos, Luz de Almeida e António Maria da Silva, mas foi parcialmente abortada, como adiante se verá. No entanto, os revolucionários estavam dispostos a matar e a morrer pelo Ideal e, a 1 de Fevereiro, D. Carlos e o Príncipe herdeiro Luís Filipe eram baleados mortalmente no Terreiro do Paço. Por ocasião do centenário do regicídio, diversas instituições científicas promoveram a realização de colóquios. Das temáticas mais em foco, podemos destacar os debates sobre a crise da Monarquia Constitucional e sobre os "autores morais" do duplo assassinato. 
O próprio haveria de confessar a sua iniciação no jornalismo, fundando o jornal O Intransigente. Sobrou-lhe em vontade, o que lhe faltava em experiência ${ }^{597} \ldots$

Em rota de colisão com os líderes das três facções ou partidos em que se fragmentou, a partir de 1911, o Partido Republicano Português, sentiu-se cada vez mais excluído e contrário à política republicana que os detentores do poder puseram em prática, mas não desistiu de fazer ouvir a sua voz e de intervir por meios mais que persuasivos. Fundou o Partido Reformista e participou na revolta militar de 27 de Abril de 1913. Apoiou o Governo do General Pimenta de Castro, que sucumbiria na ponta das baionetas e dos canhões dos revoltosos de 14 de Maio de 1915, que devolveram o poder aos democráticos ou afonsistas. Foi, então (a 17 de Maio), preso no cruzador "Adamastor", passando, por guia de 6 de Junho, para o cruzador "Almirante Reis" e "em 14 de Junho apresentou-se na Capitania do Porto de Ponta Delgada onde [fora] fixar residência por ordem do Governo, por assim o haver declarado" (Livro Mestre 3/43)598. Ora, não fora aberto qualquer processo a Machado dos Santos, pelo que a sua "deslocação" para Ponta Delgada exigia esclarecimentos por parte do Governo, que surgiram sob a forma de "nota oficiosa", datada de 13 de Junho: o afastamento do "herói da Rotunda" do Continente ficara a dever-se, exclusivamente, à necessidade de garantir a sua segurança pessoal, pois o Governo teria informações de que podia ser sujeito a atentados contra a sua vida ${ }^{599}$. Em S. Miguel, Machado Santos ainda procurou apoios para a sua candidatura à Câmara dos Deputados, mas os resultados seriam decepcionantes ${ }^{600}$. Mesmo assim, estabeleceu contactos com lideranças políticas locais, que lhe viriam a ser úteis quando assumiu a pasta do Interior no Governo de Sidónio Pais ${ }^{601}$. Em Setembro de 1915 tinha já ordem para se apresentar na Majoria General da Armada.

\footnotetext{
${ }^{597}$ SANTOS, Machado - A Ordem pública e o 14 de Maio, op. cit., p. 12-13.

598 Processo de Santos, António Maria de Azevedo Machado Santos. Oficial da Armada. Classe — Administração Naval. In Biblioteca Central da Marinha-Arquivo Central.

${ }^{599}$ Ver, por exemplo, A República. Ponta Delgada, 1915, Junho, 26. Esta "nota oficiosa" refere-se, não só à situação de Machado Santos, mas também às de Pimenta de Castro e dos seus ministros Goulart de Medeiros e Xavier de Brito, também enviados para Ponta Delgada a bordo do aviso "5 de Outubro". Desembarcaram a 14 de Junho, acompanhados do Governador Civil substituto e do Comandante Militar, tendo ficado hospedados no Hotel Açoreano (A República. Ponta Delgada, 1915, Junho, 15).

${ }^{600}$ CORDEIRO, Carlos - Nacionalismo, Regionalismo e Autoritarismo nos Açores durante a I República. Lisboa: Edições Salamandra, Lda., 1999. p. 82

${ }^{601}$ Ibidem, pp. 82-83.
} 
Entretanto, fumegavam os canhões e cavavam-se trincheiras nos campos da Flandres no decorrer da Grande Guerra de 1914 a 1918. A situação económica, social e política em Portugal agravava-se e sofria o impacto directo das consequências de um conflito bélico de tamanhas proporções. Os Governos saídos do 14 de Maio acabaram com a ambígua neutralidade beligerante e acordaram com a Grã-Bretanha a participação activa e declarada ao lado dos Aliados para defender as colónias, acautelar posições face à neutralidade de Espanha e ainda para libertar a República das dissenções internas concentrando todos, amigos e inimigos, numa causa patriótica comum e obter uma imagem internacional favorável ao regime. A conjugação desses objectivos formatou a estratégia guerrista que, apesar do inflamado patriotismo épico que a suportava, não tardaria a ser duramente contrariada pelo quotidiano da guerra vivido quer pelo Corpo Expedicionário Português (C.E.P.), desembarcado no front, mas progressivamente desapoiado ao ponto de não se concretizar a prevista substituição da tropa por novos contingentes, quer pelos portugueses no seu País, tanto nos centros urbanos, como nas vilas e aldeias, fustigados pelos açambarcamentos, pela falta dos bens essenciais, pela galopante carestia de vida...

Num quadro destes, as vozes contra a guerra surgiram e subiram de tom, entre civis e militares. E logo a 13 de Dezembro, em vésperas da partida do C.E.P. para o campo de batalha, forças hostis à beligerância movimentaram-se a partir de Tomar, para derrubar o Governo em Lisboa. À cabeça desse golpe esteve Machado Santos, juntando amigos e camaradas da marinha e do exército. O golpe falhou e os revoltosos foram presos. Entre 15 de Dezembro de 1916 e 4 de Abril de 1917, Machado Santos esteve sob prisão nos cruzadores "Vasco da Gama", "Almirante Reis" e "S. Gabriel". De Abril a Agosto desse mesmo ano, esteve recluso no Forte de S. Julião da Barra. E a 20 de Agosto recebeu ordem para ingressar na Casa de Reclusão de Viseu, onde ficou à disposição, sine die e sem processo organizado, do Tribunal Militar dessa cidade.

Seria libertado do Fontelo na sequência da eclosão, a 5 de Dezembro, do golpe liderado pelo Major de Artilharia e Lente de Matemática na Universidade de Coimbra, Sidónio Bernardino Cardoso da Silva Pais ${ }^{602}$. Encontrava-se já em

\footnotetext{
${ }^{602}$ SILVA, Armando Malheiro da - Sidónio e sidonismo. vol. 1 história de uma vida. Coimbra: Imprensa da Universidade de Coimbra, 2006. p. 402 e ss.
} 
Lisboa e era um dos membros da Junta Revolucionária quando, a 8 desse mês, os revoltosos, entrincheirados no alto do Parque Eduardo VII (local que ficou conhecido pelo "morro do Sidónio"), venceram as forças governamentais dirigidas pelo Ministro da Guerra, coronel José Mendes Ribeiro Norton de Matos, em substituição do Presidente do Ministério ausente temporariamente do País. Pouco depois, a 11 de Dezembro, era nomeado Ministro do Interior, pasta que deixou para abraçar a das Subsistências e Transportes, entre 9 de Março e 15 de Maio de 1918.

O golpe dezembrista foi concebido e preparado na sede do jornal A Luta, dirigido pelo líder da União Republicana, Manuel Brito Camacho e agregou militares desse partido e também figuras dos partidos Evolucionsita e Centrista, do médico e futuro Prémio Nobel da Medicina, António Caetano de Abreu Freire Egas Moniz. Brito Camacho tinha objectivos limitados para o golpe: era, sobretudo, necessário obrigar a facção republicana dos democráticos, a mais forte, que herdara o aparelho, a rede sócio-política e a implantação em todas as regiões em Portugal do velho P.R.P., a aceitar a dissolução do Parlamento pelo Presidente da República. Isto, no fundo, permitiria regressar a um rotativismo semelhante ao que caracterizara a Monarquia Constitucional, que os republicanos, aliás, tanto criticaram! Os camachistas não desejavam um confronto directo com Afonso Costa, nem com os seguidores de António José de Almeida. Um golpe vitorioso seria o suficiente para forçar uma negociação mediada pelo Presidente da República, Bernardino Machado, que os revoltosos, afinal, derrubaram. Muito pouco se almejava, para tanto esforço e risco!..

Foi isso o que pensaram os militares envolvidos e outros implicados. Não tardou, pois, a ruptura dos unionistas com o novo Presidente da República e chefe do Governo "ditatorial” (não sufragado pelas urnas), Sidónio Pais. A seu lado ficaram, além dos jovens cadetes da escola do exército e militares, maioritariamente do exército (uns apoiantes da participação portuguesa na Grande Guerra, outros, em largo número, anti-guerristas), Machado Santos e seus amigos, bem como os membros do Partido Centrista, embrião do Partido Nacional Republicano, que iria disputar sozinho, por não comparência das outras forças partidárias, as eleições de 28 de Abril de 1918.

O acto eleitoral legitimaria a República Nova e consagraria a experiência presidencialista e o inconsistente projecto de reformismo democrático autoritário do País através da República, com o qual Machado Santos e seus amigos, nomeadamente José Carlos da Maia e o jovem capitão engenheiro Francisco Cunha 
Leal, não exibiram uma divergência doutrinária e ideológica de fundo. Machado Santos não deixaria, aliás, de continuar à frente das Subsistências e Transportes até 9 de Junho, já não como Ministro, mas sim como Secretário de Estado, dentro da fórmula presidencialista sufragada.

O que motivou o afastamento dos machadistas teve muito a ver com discordância político-administrativa e, possivelmente, com uma desconfiança em face da crescente aproximação dos monárquicos e dos católicos dispostos a ocuparem posições na Administração civil e na estrutura militar, além de naturais reservas perante os sequazes de Egas Moniz.

A situação do País e da Europa tornara-se insustentável, nesse ano em que o Armistício seria proclamado, mas em que a pneumónica dizimou milhares de pessoas, a fome e a carestia de vida agravaram o quotidiano das pessoas por todo o lado, menos daquelas que souberam enriquecer, como sempre sucede, no meio da hecatombe bélica. E quase a findar o ano, a 14 de Dezembro, consumava-se a segunda tentativa de assassinar o Presidente Sidónio Pais, vítima mortal de um acto que não terá sido isolado, mas saído da rede conspirativa e bombista herdada do velho P.R.P. e assumida pelos democráticos de Afonso Costa ${ }^{603}$.

Com a morte de Sidónio e da sua República Nova, sobreveio a tentativa frustrada de restauração monárquica no Norte e, depois, em Lisboa, a partir de Monsanto. Desfeitas as aspirações restauracionistas, o regime de 5 de Outubro entra no segundo fôlego com a denominada Nova República Velha, sobre a qual Machado Santos não demorou a proclamar a sua insatisfação, regressando à nostálgica evocação da República de 5 de Outubro de 1910, que tardava em ser cumprida...

Apesar de mais uma aposta política falhada, Machado Santos não desistiu e fundou, em 1919, a Federação Nacional Republicana. Tentou, sem êxito, a candidatura a novo mandato como deputado por Lisboa em 1921, ano em que seria assassinado, juntamente com o seu amigo e camarada marinheiro José Carlos da Maia (1878-1921), e o líder do Partido Liberal, António Joaquim Granjo (1881-1921), durante a enigmática "noite sangrenta" de 19 de Outubro (na madrugada

${ }^{603}$ SILVA, Armando Malheiro da - Sidónio e sidonismo. vol. 2: história de um caso politico, op. cit., p. 339-366. 
do dia 20, nas ruas de Lisboa $\left.{ }^{604}\right)^{605}$, que suscitou diferentes explicações e ainda pouquíssima pesquisa rigorosa historiográfica ${ }^{606}$.

Subsiste, por isso, a questão crucial: a quem interessava, de facto, a sua morte?

\section{A Carbonária e a intrincada teia revolucionária}

Um revolucionário burocrata, por muito estranho que isso possa parecer, tende a esmerar-se no relato dos acontecimentos de que foi protagonista e através dos quais conseguiu alcançar os fins almejados.

O Relatório sobre a Revolução Portuguesa assinado pelo próprio Machado Santos $^{607}$ constitui um dos mais completos e interessantes depoimentos sobre a preparação do movimento revolucionário e os acontecimentos de 4 e 5 de Outubro de 1910. O confronto desta obra com outra documentação, mormente, periódicos, outros relatórios e livros de memórias sobre a época e os eventos retratados, permite-nos traçar, aqui, a descrição de uma "epopeia" revolucionária - militares e populares entrincheirados na Rotunda derrubam um regime multissecular. "Epopeia" a que o respectivo Herói ficou agrilhoado e incapaz de aceitar o que veio depois...

O ano de 1908 principiou com um episódio burlesco. O "28 de Janeiro" foi uma tentativa de derrube da ditadura de João Franco e de proclamação da República. Tratou-se de um singular conluio, que envolveu dissidentes monárquicos progressistas afectos a José Alpoim e sectores populares do P.R.P. e da Carbonária, dirigidos por alguns dos seus chefes políticos e militares, entre os quais se encontrava já o desconhecido e simples comissário naval Machado Santos. Este administrativo da Marinha acertara com o almirante na reserva, Cândido

\footnotetext{
${ }^{604}$ Processo de Santos, António Maria de Azevedo Machado Santos. Oficial da Armada. Classe — Administração Naval — Processo individual, caixa 142, in Biblioteca Central da Marinha-Arquivo Central.

${ }^{605}$ Ibidem. .

${ }^{606}$ Sobre o 19 (20) de Outubro de 1921 ver BRANDÃO, José - A Noite sangrenta. Lisboa: Publicações Alfa, 1991; HONRADO, Fernando - Os Fuzilados de Outubro: Lisboa - 1921. Colaboração de Maria Manuela de Moura. Lisboa: Acontecimento Estudos e Edições, 1995; ALMEIDA, J. A. Martins de - Nos meandros do 19 de Outubro. Braga: Edição do Autor, 1998.

${ }^{607}$ SANTOS, Machado - Relatório sobre a Revolução Portuguesa. Lisboa: Papelaria e Typografia Liberty, 1911.
} 
dos Reis, a sua principal missão na trama: organizar [sobretudo em Alcântara] fortes grupos de marinheiros nas diferentes unidades, que depois obedecessem às instruções dos oficiais revoltados ${ }^{608}$; e fundar, em Alfama e na Madragoa, dois grupos de civis para operar com os marinheiros ${ }^{609}$. No dia aprazado tudo correu mal. O golpe foi previamente denunciado e isso terá inibido certos oficiais, recrutados pelos conspiradores, de assumirem os seus compromissos. Depois, o sequestro planeado de João Franco, que devia servir de detonador da insurreição, acabou por não se concretizar.

As forças policiais realistas, mandatadas pelo governo, extirparam a conjura com alguma severidade: criou-se uma opressiva ambiência de estado de sítio em Lisboa; fizeram-se rusgas; prenderam-se personalidades monárquicas radicalmente descontentes, alguns notáveis do P.R.P. e cerca de uma centena de populares. Uns presumíveis conspiradores foram forçados ao exílio e outros seriam condenados sumariamente à expulsão e ao degredo. Seriam... Mas no rescaldo da intentona frustrada sectores mais intransigentes da então dispersa Carbonária, mandatados ou não pelos caudilhos do 28 de Janeiro (o caso permanece ainda por esclarecer), resolveram cortar o mal pela raiz. Quando o rei e a família real atravessavam o Terreiro do Paço, em carruagem aberta, regressados do remanso de Vila Viçosa, atiradores furtivos dispararam várias vezes, com carabinas e revólveres, de zonas diferentes da praça, e assassinaram D. Carlos e o príncipe herdeiro Luís Filipe.

Rei morto, rei posto. O jovem e infeliz D. Manuel sucedeu ao pai, depôs o controverso João Franco e deu posse a um "Ministério de acalmação". Era, contudo, tarde demais para apaziguar oposicionistas e salvar o regime da irreversível falência.

No mesmo mês, a Carbonária Portuguesa, designada, também, por Maçonaria Florestal, reorganizou-se "de cima para baixo", pela mão do discreto e melancólico bibliotecário da Biblioteca Central da Câmara Municipal de Lisboa, Artur Luz de Almeida, para operar um novo e derradeiro levantamento contra a Monarquia. O grão-mestre conhecia bem o temperamento jovial, combativo, obstinado, carismático, e as convicções políticas de Machado Santos desde os tempos do liceu,

\footnotetext{
${ }^{608}$ Ibidem, p. 11.

${ }^{609}$ Ibidem, p. 17.
} 
quando os colegas o consagraram com a alcunha de "Presidente da República do Cartaxo" ${ }_{10}$. Conhecia, também, o seu anterior envolvimento em actividades conspirativas, sabia a opinião céptica que ele sustentava sobre a hipótese de um pronunciamento de oficiais e a esperança que depositava na organização de um levantamento popular, comandado por capitães e subalternos, inspirado no exemplo da "jovem Turquia"

Quando, em Julho, Machado Santos desembarcou em Lisboa, acabado de chegar de uma comissão de serviço na Guiné, cobrada como castigo pelas suas actividades subversivas, foi contactado por Luz de Almeida e logo iniciado na sua sociedade secreta da Venda "Jovem Portugal", numa cerimónia eivada de liturgia ${ }^{612}$. E a sua ascensão foi bastante célere. No mesmo mês, foi eleito, por unanimidade, "presidente" com funções executivas da Alta Venda, em conjunto com o engenheiro civil dos Correios e Telégrafos António Maria da Silva, que conheceu aquando do 28 de Janeiro. Tratava-se do órgão directivo de topo da Carbonária Portuguesa, que aglutinava e controlava as choças, barracas e vendas. Começou, de imediato, a trabalhar, com invulgar vigor e perseverança, para derrubar a Monarquia e instaurar a República.

As dificuldades que o triunvirato constituído por Luz de Almeida, Machado Santos e António Maria da Silva enfrentou, na época, a fim de cumprir os seus objectivos foram muitas: reorganizar e regulamentar a Carbonária e convencer o directório do P.R.P. das boas intenções desta associação secreta; recrutar e doutrinar para a causa, de forma sistemática, civis, marinheiros e soldados dos regimentos e cidades da "província" e, sobretudo, de toda a guarnição militar de Lisboa; aliciar oficiais e, pelo menos, um general do exército que se prestasse a assumir a direcção superior das forças em terra; obter armas e financiamentos; e arquitectar um plano infalível capaz de convencer todos os republicanos.

Esta "missão impossível" foi cumprida e Machado Santos desdobrou-se em várias tarefas, com "inigualável dedicação"113 e "uma fé inquebrantável”"14, por

\footnotetext{
${ }^{610}$ ALMEIDA, A. Luz, O amigo Machado Santos. O Intransigente, número único em sua homenagem, 2 de Julho de 1922.

${ }^{611}$ MELO, J. A. Fontes Pereira de - A revolução de 4 de Outubro (subsídios para a História). Lisboa: Guimarães \& C. ${ }^{a}$ Editores, 1912. p. 20.

${ }^{612}$ SANTOS, Machado - Relatório, op. cit., p. 29.

${ }^{613}$ SILVA, António Maria da - O meu depoimento. 1. ${ }^{\circ}$ vol. Lisboa: 1974. p. 239.

${ }^{614}$ RELVAS, José - Memórias políticas. vol. 1. Lisboa: Terra Livre, 1977, p. 72.
} 
vezes com uma temeridade louca e "sem guardar retirada" ${ }^{15}$ : aliciou e alistou novos primos, provenientes de meios proletários e pequeno-burgueses da cidade de Lisboa, de "todas as nuances partidárias" ${ }^{16}$, entre as quais cabiam também sectores anarquistas da extinta Carbonária Lusitana; despertou o sentimento anti-monárquico dos neófitos carbonários, através de arrojados comícios organizados na Serra de Monsanto e noutros recantos de Lisboa, e da redacção de folhetos de propaganda sectária como Os Barbadões, onde desancava em todos os descendentes da Casa de Bragança que foram reis de Portugal (corja de "beatos clericais", "loucos", "ditadores sanguinários" e incompetentes sem perfil de estadistas) e proclamava o messianismo republicano ${ }^{617}$; angariou fundos para obter bombas e armas; engendrou, numa dependência da sua casa, sucessivos planos mais ou menos fantasistas e sempre adiados de deposição da Monarquia; e ainda se envolveu numa mediática polémica corporativa, quando resolveu assinar um artigo no jornal O Radical — "A promoção dos segundos tenentes da Armada" (27 de Julho de 1908) - onde denunciou o estado decrépito da frota naval nacional e acusou os oficiais da Marinha, com assento na Câmara dos Deputados, de cuidarem dos seus interesses privados e silenciarem os problemas desta força militar.

A sua frenética actividade não passou despercebida aos poderes instituídos. A polícia, equivocada, assaltou e vasculhou um andar contíguo à sua casa, submeteu-O a apertada vigilância e terá chegado a atentar contra a sua vida ${ }^{618}$. $\mathrm{O}$ artigo que escreveu n'O Radical originou a perseguição desencadeada pelos visados e pelo próprio Ministro da marinha, mas suscitou também a solidariedade imediata dos seus correligionários republicanos, que aplaudiram em pleno parlamento, pela voz do grande "tribuno popular" António José de Almeida, a "crítica viva, mas primorosa" e "correctíssima" 19 do seu escrito, e prestaram-lhe homenagem. No entanto, esse acto levou-o a Conselho de Guerra de onde saiu absolvido. A absolvição não significou o perdão. No rescaldo da sentença foi

${ }^{615}$ SILVA, António Maria da - O meu depoimento, op. cit., p. 237; RELVAS, José - Memórias política, op. cit., p. 72.

${ }^{616}$ SANTOS, Machado - Relatório, op. cit., p. 31.

617 “'Os Barbadões' - folheto atribuído a Machado Santos”. In História Contemporânea da Portugal (dir. João Medina), op. cit., pp. 21-24.

${ }^{618}$ MADUREIRA, Joaquim - Caras Lavadas, op. cit., pp. 36-37.

${ }^{619}$ Diário das Sessões da Câmara dos Deputados, 10 de Agosto de 1908. 
nomeado para uma nova comissão de seis meses de serviço em África e partiu para Angola a bordo do navio de transporte Pêro de Alenquer.

Em Outubro de 1909, não obstante ter perdido os préstimos de Luz de Almeida, que entretanto foi forçado a exilar-se após o célebre "crime de Cascais" a Carbonária teria, de acordo com as estimativas mais optimistas, "34 000 agremiados”,21, e, então só liderada por Machado Santos e por António Maria da Silva, estava já em condições de influenciar uma decisão do P.R.P. sobre a perene questão da revolução. E foi o que fez no congresso de Setúbal, em Abril de 1909. O novo directório do P.R.P., eleito nesse congresso também com os votos dos delegados da Alta Venda ${ }^{622}$, nomeou uma comissão executiva constituída por Cândido dos Reis, António José de Almeida (que arcava já com as funções de "embaixador oficioso da Carbonária junto do directório"(623), Afonso Costa e João Chagas. Este organismo devia contactar militares e civis, conectar-se com a Alta Venda e organizar a revolução.

Depois de um momento de letargia, e pressionada pelos temerários chefes da Carbonária (mormente, por Machado Santos) e pelos desejos ansiosos de muitos dos seus activistas, sobretudo da Armada, de embarcar em qualquer plano mais estouvado, esta comissão civil recrutou uma comissão militar revolucionária, composta por três oficiais (o capitão Afonso Pala, o capitão de fragata Fontes Pereira de Melo e o coronel Ramos da Costa), que reuniu "algumas dezenas de vezes", para angariar e congregar outros oficiais em todas as armas, arquitectar,

\footnotetext{
${ }^{620}$ Tratou-se do assassinato de Manuel Nuno Pedro, ocorrido no lugar da Boca do Inferno (próximo de Cascais), em 19 de Outubro de 1909. A vítima teria furtado munições de um armazém da Alfândega para as vender a conspiradores republicanos. Fugiu, em seguida, para Espanha, mas logo regressou a Lisboa para extorquir dinheiro aos compradores, com o argumento de que os denunciava à polícia. Estes acabaram por marcar um encontro na Boca do Inferno com o chantagista e — premeditadamente, ou não - empurraram-no do cimo de uma falésia. O crime foi depois aproveitado pelo poder instituído para atingir Luz de Almeida (que foi obrigado a exilar-se) e o Partido Republicano. António Maria da Silva afirmou mais tarde, num depoimento pouco isento, que "o denominado Crime de Cascais não foi da responsabilidade da Associação nem o atingido pertencia à Carbonária" (SILVA, António Maria da - O meu depoimento, op. cit., p. 191).

${ }^{621}$ ALMEIDA, Luz de - "As sociedades secretas na revolução". In História do regime republicano em Portugal. vol. II. Lisboa: Edição de Luís de Montalvor, 1932, p. 251.

${ }^{622}$ SILVA, António Maria da - O meu depoimento, op. cit., p. 207.

${ }^{623}$ SANTOS, Machado - Relatório, op. cit., p. 31; SILVA, António Maria da - O meu depoimento, op. cit., pp. 204-207.
} 
com rigor, um plano insurreccional onde os regimentos pudessem dispensar os seus comandantes e dirigir a revolta ${ }^{624}$.

Face às sucessivas hesitações e presumíveis inoperâncias da dita comissão militar e à desconfiança permanente que o directório e os notáveis do PRP nutriam por essa comissão militar e pelas intenções e habilitações da "canalha" da Carbonária, que na rua devia complementar a revolução ${ }^{625}$, Machado Santos solicitou à Maçonaria Portuguesa, através da sua loja Montanha ${ }^{626}$ a convocação de uma assembleia-geral. O grão-mestre adjunto, José de Castro, anuiu e, no dia 14 de Junho de 1910, realizou-se uma "imponente" reunião do Grande Oriente Lusitano $^{627}$. Aí foi eleita uma comissão de resistência, presidida por José de Castro, que integrava elementos de todas as lojas maçónicas (dela faziam parte Machado Santos, António Maria da Silva, Cândido dos Reis, Miguel Bombarda, Francisco Grandela, J. Cordeiro Júnior e Simões Raposo) e ficou encarregada de congregar sinergias no P.R.P., nos militares e nas associações secretas com o firme propósito de pôr a revolução na rua ${ }^{628}$.

De facto, a desconfiança, os desentendimentos e a intriga minavam e corroíam os elementos que compunham o directório, os militares e todas estas comissões e associações secretas. Factores nocivos que retardavam a revolta e agastavam as humildes massas revolucionárias de tropas e civis que nos quartéis e nas ruas "davam o corpo ao manifesto" e sofriam acções de coacção ou repressão. Alguns oficiais - os tenentes Aragão e Melo e Hélder Ribeiro e o capitão Sá Cardoso - , instados por Machado Santos, António Maria da Silva e Cândido dos Reis, já depois de rendidos à demonstração de força evidenciada, em 2 de Agosto de 1910, pelas disciplinadas paradas de carbonários nas ruas de Lisboa, concordaram em constituir uma subcomissão e elaborar um plano alternativo

624 "Relatório de Afonso Pala sobre a revolução". In Relatórios sobre a revolução de 5 de Outubro, op. cit., 1978, p. 60; MELO, J. A. Fontes Pereira de Melo - A revolução de 4 de Outubro, op. cit., ps. 18 e 56.

${ }^{625}$ MELO, J. A. Fontes Pereira de - A revolução de 4 de Outubro, op. cit., pp. 44-45.

${ }^{626}$ Luz de Almeida afirmou que a Loja Montanha foi formada por carbonários e constituiu o "veículo da Carbonária dentro da Maçonaria": ALMEIDA, Luz de - "A obra revolucionária de propaganda: as sociedades secretas". In História do regime republicano em Portugal. vol. II, op. cit., p. 219.

${ }^{627}$ SANTOS, Machado - Relatório. op. cit., p. 49; SILVA, António Maria da - O meu depoimento. op. cit., p. 259.

${ }^{628}$ SANTOS, Machado - Relatório, op. cit., pp. 48-49; SILVA, António Maria da - O meu depoimento, op. cit., pp. 259-260. 
da revolução à revelia da comissão militar e do directório do PRP. O plano foi gizado, em Setembro de 1910, mas contou logo com as inevitáveis objecções de outros oficiais e políticos republicanos sem fé revolucionária. Porém, o tempo escasseava e precipitava a escolha do dia do golpe, pois as denúncias faziam avançar as diligências policiais e obrigavam o Governo a tomar medidas de urgência bruscamente agravadas com os tumultos e as manifestações causadas pelo homicídio do médico republicano e anticlerical Miguel Bombarda, assassinado a tiro por um louco a 3 de Outubro, e a visita oficial ao País do Presidente da República do Brasil, Hermes da Fonseca, de 1 a 6 de Outubro. Essas medidas foram, mais uma vez. o abandono da Armada do Tejo, decretado para o dia 4, e o estado de prevenção nos quartéis. Contudo, apesar dos riscos agravados, desta vez não havia retorno.

Numa reunião ocorrida às 16 h00 do dia 2 de Outubro, no escritório de Eusébio Leão, em pleno Chiado, oficiais, chefes maçons e carbonários e o directório chegaram a um difícil consenso, fixaram a data de 4 de Outubro, à 1 da manhã, adoptaram o plano de combate já engendrado pela subcomissão atrás mencionada e escolheram a senha que os revolucionários trocariam: — "Mandou-me procurar?... Passe, cidadão!". O directório do P.R.P. aceitava a acção da Maçonaria e da Carbonária; em contrapartida, estas sociedades secretas admitiam que o partido arrecadasse os louros da vitória e nomeasse o Governo provisório, os governadores civis e do ultramar, os directores-gerais e os representantes do novo poder republicano português no estrangeiro ${ }^{629}$.

Machado Santos considerou, depois, que esta decisão veio a revelar-se "desgraçada" ${ }^{30}$ para o novel País republicano, porquanto a escolha dos novos políticos para os mais altos cargos da Nação resultou de um directório que estava minado por velhas e insanáveis rivalidades e questiúnculas. Outro destacado protagonista da revolução, José Relvas, não deixou também de notar, nas suas Memórias Politicas, outra obra memorável sobre a revolução de Outubro, as inquietantes "divergências" que logo emergiram no seio do directório relativ

\footnotetext{
${ }^{629}$ SANTOS, Machado - Relatório, op. cit., p. 57.

${ }^{630}$ Ibidem, pp. 57-58.
} 
mente à constituição do "Ministério da Revolução" e que tanto vieram afectar "os destinos das novas instituições"

No dia seguinte, a comissão de resistência da Maçonaria reuniu no Centro de S. Carlos para os últimos preparativos. Machado Santos ofereceu-se para revoltar o regimento de Infantaria 16 que, embora contasse com a adesão de muitos soldados e cabos, não dispunha de qualquer oficial ou sargento republicano. E avisou logo que não desejava a presença no local de "qualquer pessoa importante do partido" ${ }_{32}$. Para o comissário naval, o "velho e porfiado desejo de comandar uma unidade de terra" superava o risco evidente da missão633.

Houve, ainda, uma derradeira e agitadíssima reunião, às 20 h30 do dia 3, num terceiro andar do prédio n. ${ }^{\circ} 106$ da Rua da Esperança, à Madragoa, que pertencia à mãe de Inocêncio Camacho, oportunamente transferida para Sintra. Numa acanhada e "irrespirável" ${ }^{34}$ sala dessa casa que transbordava de conspiradores mais notáveis, perante novas e graves hesitações manifestadas por civis e militares, o almirante Cândido dos Reis - designado comandante chefe da revolução - apresentou aos perplexos oficiais da comissão militar, pela primeira vez, o calendário e o plano de combate, apelou ao patriotismo de todos e teria vociferado: - República ou morte. "Se a revolta fracassar damos um tiro nos miolos" 35 . Irónica profecia para quem na noite do dia 4, confrontado com o espectro da derrota, optou por suicidar-se com um disparo de revólver! O pobre capitão de fragata João Fontes Pereira de Melo, membro da comissão militar, revelou depois, com notória amargura e ambiguidade, como nessa reunião se sentiu "desprezado" por outros "camaradas" que levados pela "inveja", o "egoísmo" e a "desmedida ambição", "tiveram uma noite feliz preparada pelo trabalho da sua comissão" ${ }^{36}$. Na "suprema confusão e verdadeiro caos"637 desse encontro, foi ainda fixado um polémico sinal de aviso para o início das hostilidades que nem

\footnotetext{
${ }^{631}$ RELVAS, José - Memórias políticas, 1, op. cit., pp. 98-99.

${ }^{632}$ Ibidem, p. 61.

${ }^{633}$ SILVA, António Maria da - O meu depoimento, op. cit., p. 283.

${ }^{634}$ ABREU, Jorge de - A Revolução Portuguesa. O 5 de Outubro. Lisboa: Edição da Casa Alfredo David, 1912. p. 125.

635 SILVA, António Maria da - O meu depoimento, op. cit., p. 285.

${ }^{636}$ MELO, J. A. Fontes Pereira de - A revolução de 4 de Outubro, op. cit., 1912. pp. 56-59.

${ }^{637}$ Ibidem, p. 63.
} 
todos compreenderam: uma salva de três ou 31 tiros (!) disparados de bordo dos navios de guerra fundeados no Tejo.

Mais tarde, alguns oficiais conjurados justificaram a sua inacção na revolta por não terem ouvido o sinal acordado. Machado Santos, mais dado à acção do que a teorias cépticas recorrentes e conselhos demasiado racionais sobre o sentido prematuro e improcedente da revolução, não compareceu ao último conciliábulo porque tinha já interiorizado que, desta vez, ninguém podia deter a marcha dos acontecimentos. E procedia em conformidade: à mesma hora, dirigiu-se para o Centro Republicano de Santa Isabel, em Campo de Ourique, para se encontrar com os carbonários que o iriam acompanhar na sublevação do quartel de Infantaria 16. A partir deste momento, já nada nem ninguém podia parar o "processo revolucionário em curso".

\section{A batalha, em Lisboa, pela República para o Povo...}

À uma hora da noite serena e estrelada do dia 4 de Outubro, uma terça-feira, o jovem segundo-tenente José Mendes Cabeçadas assumiu o comando do cruzador Adamastor e ordenou o disparo de três tiros, e não 31 de canhão, como constou depois, que anunciavam o início da revolução.

Cerca de 15 minutos antes, Machado Santos, trajado com a sua "farda de gala”338, acompanhado de 16 bons primos (carbonários) mal armados, tinha já entrado de rompante pela porta de uma arrecadação do quartel de Infantaria 16, em Campo de Ourique, onde foi repelido pelos oficiais presentes, mas recebido com júbilo pela maioria dos cabos e dos soldados previamente doutrinados nos ideais republicanos. O seu primeiro objectivo estava cumprido, ainda que tenha ditado a morte do comandante e de um capitão do mencionado regimento. Daqui partiram cerca de 200 homens, no meio de grande "confusão" e "entusiasmo"(639, encabeçados por Machado Santos, rumo a Campolide, ao encontro do regimento de Artilharia 1. Neste quartel, as referidas forças, agora comandadas pelo capitão Sá Cardoso, que os esperava à porta, arrombaram a porta de armas,

\footnotetext{
${ }^{638}$ SANTOS, Machado - Relatorio, op. cit., p. 65.

${ }^{639}$ O Mundo publica a primeira entrevista com Machado Santos. O Mundo, 12 de Outubro de 1910.
} 
juntaram-se aos elementos, entretanto, sublevados, por acção do capitão Afonso Pala e alguns sargentos, e recolheram várias peças de artilharia.

Em seguida, formaram-se duas colunas que deveriam juntar-se a outros regimentos revoltados: uma marchou rumo ao Palácio das Necessidades, para aprisionar o rei; e outra avançou para S. Roque, com a intenção de atacar e neutralizar o quartel-general da Guarda Municipal, situado no Carmo. Porém, os recontros com a Guarda Municipal fundiram de novo as duas colunas, agora sob o comando do capitão Sá Cardoso, obrigaram à alteração dos planos e conduziram-nas, "no meio de grande confusão"640, à Avenida da Liberdade, ou seja, o burguês Passeio Público, com o propósito de progredirem sobre o Rossio. Acossados por um "ataque vigoroso"641 da cavalaria da Guarda Municipal que subia a Avenida, os revoltosos recuaram, entrincheiraram-se na rotunda da Avenida, então já conhecida por Praça Marquês de Pombal, e resistiram à ofensiva da guarda pretoriana do regime. Seriam, então, 5h00 da madrugada.

Na Rotunda, ao romper da manhã, os oficiais reuniram. Sentindo-se cercados pelo adversário, abandonados pelo directório do P.R.P. e, também, por outros oficiais, e receando um banho de sangue, decidiram que a derrota militar seria incontornável ${ }^{642}$. Às 9h00, trocaram os uniformes por vestuário de paisanos e resolveram desertar. Mas Machado Santos, persuadido por outros revolucionários, pensou de forma diferente. Pensou no dramático futuro dos "pobres" soldados e, decerto, de si próprio, que em caso de derrota seriam vítimas de uma "hecatombe"643. Pensou que as forças militares leais à Monarquia estavam contaminadas por soldados e marinheiros republicanos doutrinados por ele durante "todas as noites ao longo de ano e meio, sem afrouxar um só momento" ${ }^{44}$. Pensou na superioridade das suas forças, no domínio da artilharia. Pensou numa súbita acção heróica dos bons primos da sua Carbonária, cujo poder ainda se conservava latente ${ }^{645}$. Teve conhecimento do triunfo da revolução na margem sul do Tejo, (mais precisamente

${ }^{640}$ ABREU, Jorge de - A Revolução Portuguesa, op. cit., p. 135 e pp. 178-180.

${ }^{641}$ SANTOS, Machado - Relatório, op. cit., p. 71.

642 "Relatório do capitão de artilharia José Afonso Pala". In Relatórios sobre a revolução de 5 de Outubro, op cit., p. 76; ABREU, Jorge de - A Revolução Portuguesa, op. cit., pp. 144-146; CASTRO, Armando de - A Revolução Portuguesa, $3 .^{\circ}$ vol., op. cit., pp. 744-745.

${ }^{643}$ SANTOS, Machado - Relatório, op. cit., pp. 72-73.

${ }^{644}$ Ibidem, p. 73

${ }^{645}$ Ibidem, p. 74 
no Barreiro e na Moita) ${ }^{646}$, e foi, ainda, convencido de que a revolta da Marinha tinha vingado em Alcântara e no Tejo, pelo que o desembarque dos "camisolas de alcaixa” ${ }^{647}$ seria inevitável ${ }^{648}$. Reuniu, então, com os nove sargentos resistentes, assumiu o comando de Infantaria 16 e Artilharia 1 e assegurou a defesa do local entre "teóricas barricas" construídas com madeira, fios telegráficos, troncos de árvore e chapas de zinco $^{649}$, e contabilizou as suas forças: cerca de 200 militares e uma multidão indisciplinada, mas voluntariosa de civis; e oito peças de artilharia que assestou nas embocaduras das principais avenidas.

Neste ponto da nossa narrativa, será pertinente referir que, em 1912, o jornal operário A Batalha chegou a contestar o facto de Machado Santos ter chefiado até ao final os resistentes da Rotunda ${ }^{650}$. Alegou, então, este periódico que o tenente de infantaria do quadro da reserva, Fernando Mauro de Assunção Carmo, teria recebido do próprio comissário naval (e, portanto, menos graduado) o comando das forças amotinadas, no desassossego da refrega do dia 4 de Outubro, logo após a fuga dos oficiais, e assumido as maiores responsabilidades até ao fim do combate. Todavia, este oficial e carbonário acabaria por ser "acometido de um acesso cerebral", depois das 17 h00 do dia 6, vítima de fadiga e de um ferimento na perna direita sofrido no dia $5^{651}$. Foi, por isso, transportado para o hospital da Estrela, onde permaneceu até ao dia 12 ou 13. Terá sido, entretanto, esquecido por Machado Santos, o qual afirmou, depois, desconhecer a militância na Carbonária do tenente Carmo e, sobretudo, silenciado a sua acção de comando na Rotunda, para desse modo usurpar por inteiro a glória que caberia por direito a este militar. O tenente Carmo viria, inclusive, a pedir, através de um requerimento, datado de 16 de Novembro de 1911, para ser submetido a um Conselho de Guerra, porque, como afirmava nesse documento, "fez parte do exército republicano desde 4 de Outubro de 1910 e presidiu aos destinos da Rotunda nos dias 4, 5 e 6", na qualidade de "único oficial mais graduado" e foi depois preterido e privado das

\footnotetext{
${ }^{646}$ SILVA, António Maria da - O meu depoimento, op. cit., p. 306.

${ }^{647}$ Marinheiros.

${ }^{648}$ RELVAS, José - Memórias politicas, op. cit., p. 141.

${ }^{649}$ SANTOS, Machado - Relatório, op. cit., 1911, p. 79.

${ }^{650}$ A Batalha, 5, 12, 19 e 26 de Outubro de 1912.

${ }^{651}$ A Batalha, 5 de Outubro de 1912.
} 
regalias consignadas na lei militar que foram atribuídas a outros militares republi$\operatorname{canos}^{652}$. O seu pedido acabou por ser indeferido e o caso esquecido.

A defesa de Machado Santos (convém esclarecer que esta denúncia do periódico sindicalista surgiu tardiamente — só em 1912!) foi inconsequente e ignorou que o então comissário naval tinha citado por três vezes o "valioso auxílio" do "incansável" tenente Carmo no seu Relatório sobre a Revolução Portuguesa ${ }^{653}$ e que no Relatório de Recompensas o recomendou para ser promovido a major ${ }^{654}$. Acresce ainda que muito antes deste ataque frontal dirigido à honra e orgulho do operacional republicano ter deflagrado, já a Assembleia Nacional Constituinte havia aprovado — no dia 3 de Julho de 1911 —, com 149 votos a favor e 14 rejeições, uma extraordinária proposta de lei, que reconheceu o "feito heróico" do então "segundo tenente da administração naval" Machado Santos em prol da proclamação da República e, por isso, o promoveu a capitão de mar e guerra e concedeu-lhe uma pensão anual de 3000 reis livres de quaisquer direitos e impostos ${ }^{65}$. Portanto, a decisão tomada nessa altura pelos parlamentares do novo regime parecia demonstrar o prestígio que o "triunfador" da Rotunda ainda gozava junto dos influentes meios políticos republicanos e, sobretudo, consagrava ad perpetuam o papel preponderante que assumira na revolução de 5 de Outubro.

Mas mergulhemos de novo na vertigem da refrega.

Desde as $12 \mathrm{~h} 30$ do dia 4, a Rotunda e o quartel de Artilharia 1 foram bombardeados com sucessivas granadas e ripostaram, forçando, cerca das 16h00, a retirada das baterias de Queluz comandadas por Paiva Couceiro, que disparavam da zona de Campolide (de uma quinta próxima do quartel de Artilharia 1) e da Penitenciária. O tempo e a reacção pouco enérgica dos sitiantes revertiam a favor dos republicanos, que tinham já acordado entre si o desembarque dos marinheiros e a fusão destes com as forças da Rotunda.

Depois dos combates da tarde, a Praça Marquês de Pombal estava "completamente cheia de povo". Às 20h00, o número de militares e civis armados na

${ }^{652}$ A Batalha, 19 de Outubro de 1912.

${ }^{653}$ SANTOS, Machado - Relatório, op. cit., pp. 82, 159 e 168.

${ }^{654}$ SANTOS, Machado - "Relatório de recompensas do comandante Machado Santos aos membros do Governo Provisório da República”. In Relatórios sobre a revolução de 5 de Outubro, op cit., p. 48.

${ }^{655}$ Diário da Assembleia Nacional Constituinte, 12. ' Sessão, 3 de Julho de 1911. 
Rotunda aumentava para 1000, aos quais se deve juntar mais cerca de 500 civis desarmados. Entre estes, muitos regressaram à noite a suas casas para jantar ${ }^{656}$. Os vários e desencontrados relatos memorialistas da revolução revelam o ambiente tragicómico que aí se vivia. Uns destacam que o acampamento "era um caos de indisciplina e de confusão" ${ }^{657}$, outros distinguem a presença de "150 pessoas válidas, entre civis e militares capazes de fazerem frente ao inimigo", porque as restantes eram "rapaziada bravia, armada de ferros de vários tamanhos e feitios, machados, bainhas de espada e sabres [...], tudo armamento que só servia para matar carriça" ${ }^{\circ 5}$, e outros ainda registam o ambiente "que mais parecia de festa do que de revolução"659.

Pelas 23h00, voltaram a estoirar petardos, bombas, granadas e balas, facto que se prolongou por algumas horas noite dentro. Depois, venceu um silêncio enganador, entrecortado por detonações mais ou menos solitárias, e pairou um "relativo sossego talvez de duas horas". Até que às 6h00 da madrugada do dia 5, foram os revoltosos da Rotunda, logo guarnecidos pela Artilharia 1 de Campolide, que abriram as hostilidades contra o Rossio e as baterias de Queluz, então, já posicionadas a sul da Avenida, nas imediações do Rossio, enquanto aguardavam pelo desembarque dos marinheiros oriundos dos navios "Adamastor", "S. Rafael" e do "D. Carlos", que foi o último a revoltar-se. Na noite do dia 4, os marinheiros, coadjuvados por alguns civis, tinham subjugado os navios atrás mencionados, tomado o seu quartel, em Alcântara, e tentado, sem êxito, avançar sobre o Palácio das Necessidades.

O desembarque teve início pelas 5 h00 do dia 5. Mas bem antes disso, desde a tarde do dia anterior, o "Adamastor" e o "S. Rafael" tinham bombardeado o Palácio das Necessidades, o Terreiro do Paço, o Arsenal do exército e o Rossio. Com isso forçaram a fuga do rei e feriram irreversivelmente a moral dos comandantes das tropas monárquicas. O desembarque dos marinheiros no Terreiro do Paço engastou as forças realistas entre dois fogos — os sitiantes tornavam-se sitiados. Quando essas forças pretenderam retorquir, os seus generais

\footnotetext{
${ }^{656}$ SANTOS, Machado - Relatório, op. cit., 1911, p. 84.

${ }^{657}$ NEVES, Hermano - Como triunfou a República. Lisboa: Empresa Editorial "Liberdade", 1910, p. 108.

${ }^{658}$ STEFFANINA, Celestino - Subsídios para a bistória da Revolução de 5 de Outubro de 1910. Lisboa: Edição de autor, 1918, p. 12.

${ }^{659}$ PATRÍCIO, Arthur - Na barricada da Rotunda, Lisboa: Centro Typographico Colonial, 1912, p. 28.
} 
descobriram que elas estavam minadas por soldados e oficiais republicanos que se recusaram combater.

O destino da revolução estava traçado. Será, porém, consumado de forma inesperada. Entre as 7 h00 e as 8 h00 da manhã, um pavilhão branco foi içado no quartel-general e na Avenida da Liberdade. Era o encarregado de negócios da Alemanha que pretendia parlamentar, com o propósito de negociar um armistício que permitisse a evacuação das famílias estrangeiras residentes em Lisboa.

Machado Santos acedeu enquanto os seus homens convertiam, com êxito, os soldados de cavalaria que escoltavam o diplomata alemão. Mas, poucos minutos antes do início do cessar-fogo, partiu do acampamento da Rotunda, confiante e orgulhoso, rumo ao Rossio, ao encontro da multidão que daí emergia. Montava o manso cavalo branco que havia exigido para dirigir os amotinados e há muito povoava o seu imaginário, como narrou, pitorescamente, A. Maria da Silva ${ }^{660}$. O povo, já em absoluto estado de euforia, recebeu-o a meio da Avenida, "arrancou-o" do cimo do cavalo e levou-o em triunfo ao quartel-general de S. Domingos, onde, segundo sustenta no seu Relatório, impôs a rendição ao general Manuel Rafael Gorjão ${ }^{661}$.

Aqui e em muitos outros pontos, a narrativa confusa, às vezes antinómica, e demasiado narcísica de Machado Santos, é contraditada por diversos protagonistas da revolução. Com efeito, outros relatórios, depoimentos e livros de memórias sustentam que quando o comissário naval entrou no quartel, a vitória republicana estava consumada, pois o povo e depois os marinheiros tinham invadido pacificamente o Rossio, desde o momento em que foi hasteada a bandeira branca, e logo confraternizaram com as tropas realistas de Infantaria 5 e Caçadores 5. Assim, estas não se teriam rendido, mas antes "negado positiva e categoricamente fazer fogo sobre os revoltosos" e, "pela sua firme atitude", imposto a proclamação da República ${ }^{662}$. Alguns desses textos esclarecem ainda que o

\footnotetext{
${ }^{660}$ SILVA, António Maria da - O meu depoimento, op. cit., 1974, p. 283.

${ }^{661}$ SANTOS, Machado - Relatório, op. cit.,1911, p. 90.

${ }^{662}$ Cf. Relatório de Infantaria n. ${ }^{\circ}$, pelo capitão Ascensão Valdês (pp. 93-114); Conduta do batalhão de Caçadores n. 5 na revolução que precedeu a proclamação da república, pelo capitão Carvalhal Correia Henriques (p. 129); "Notas de um oficial revolucionário, Alferes de caçadores n. 5 Ernesto Gomes da Silva Jr." (p. 147). In Relatórios sobre a revolução de 5 de Outubro, Lisboa: Publicações Culturais da CML, 1978; e MARTINS, Mariano - "A minha missão no dia 5. Depoimentos d`um revolucionário”. Ilustração Portuguesa, 5 de Junho de 1911.
} 
representante do directório presente no local, José Barbosa, tinha já dado o seu acordo para que o comando do quartel-general fosse transferido para o general António de Carvalhal ${ }^{663}$; outros asseguram que quando Machado Santos chegou ao quartel-general já este "estava nas mãos dos republicanos, já o Governo Civil se tinha rendido, já a República se tinha proclamado na Câmara Municipal" E por isso Machado Santos não impôs, mas foi, quando muito, ratificar a rendição dos monárquicos.

Cerca das 9h00 da manhã resplandecente do dia 5 de Outubro, Eusébio Leão e Inocêncio Camacho proclamaram, majestosamente, o advento da República e anunciaram a constituição do Governo Provisório, da varanda do edifício da Câmara Municipal de Lisboa. Esta imagem passou, de resto, a constituir um dos ícones do regime ${ }^{665}$. Depois, como havia imaginado o malogrado Cândido dos Reis, a vitória em Lisboa provocou a adesão imediata da província. Também João Chagas pensou assim, quando profetizou que este regime providencial se proclamaria pelas armas na capital e chegaria ao resto do País por telégrafo.

\section{De Herói a Intransigente...}

A revolução resultou da acção de demasiadas forças centrífugas, que revelaram sempre dificuldades para superar as suas divergências e produzir uma síntese comum. Referimo-nos, evidentemente, ao P.R.P., onde devemos incluir o directório, as comissões civil e militar e os notáveis de diferentes facções que foram excluídos destes organismos, à Carbonária e à Maçonaria (e a sua comissão de resistência, as suas inconciliáveis células e as suas lojas) e à Junta Liberal. Essa ausência de unidade e de coordenação ficou, de resto, bem demonstrada nos dias da insurreição, onde quase nada parece ter acontecido conforme o planeado, e ficou também estampada na subsequente acção do Governo Provisório. Mas o que sucedeu naquela data histórica não foi nem um "milagre" nem um "bambúrrio", como os tutores ou detractores de uma certa República preten-

\footnotetext{
${ }^{663}$ ABREU, Jorge de - A Revolução Portuguesa, op. cit., p. 200-201.

${ }^{664}$ STEFFANINA, Celestino - Subsídios para a história da Revolução..., op. cit., p. 25.

${ }^{665}$ LEÃO, Eusébio - "Como se proclamou a república". Ilustração Portuguesa, 23 de Janeiro de
} 1911. 
deram apregoar. No momento decisivo, a vitória dos republicanos deve ser assacada à abstenção das forças militares que, supostamente, deviam lealdade ao rei, mas que, afinal, estavam já convertidas ao espírito da prometeica aurora republicana. E deve, também, ser atribuída à inacção militar, incompetência e falta de convicção política dos generais e Governo da monarquia, que, afinal, e dadas as circunstâncias, se renderam ao fim inevitável do provecto regime.

Importa ainda acrescentar que, por detrás dos soldados e marinheiros, dos operacionais da Carbonária e dos "magotes de povo"666 que nos dias 4 e 5 de Outubro participaram e, depois, festejaram efusivamente a revolução nas avenidas e praças de Lisboa, estiveram homens bem identificados. Enfim, os mestres e artífices da revolução. Líderes civis cuja acção política foi decisiva para desgastar o regime monárquico e preparar a insurreição, mas que nos dias dos confrontos ficaram na retaguarda e assumiram uma posição mais ou menos expectante. Primeiro, no estabelecimento de banhos de S. Paulo, depois, nos Hotéis Europe e Central e na redacção do periódico A Luta, ou — os mais inconformados - a integrarem missões de mensageiros entre as forças sublevadas. E líderes militares, sobretudo de baixa patente — sargentos, cabos, comissários navais, tenentes e capitães - que arquitectaram o "golpe de mão"6r7 letal e assumiram, de forma mais ou menos corajosa, as despesas desse combate, que explodiu sobretudo nas ruas da capital do País. Vários deles, de uma forma ou de outra, empenharam a sua vida pessoal e familiar até aos limites do admissível na luta por um ideal em que acreditaram: a queda da "decrépita e desacreditada"668 Monarquia e... o advento da República - essa aspiração messiânica, mas vaga, indefinida e utópica, que, por isso, depois de 5 de Outubro de 1910, ninguém conseguiu materializar num regime estável, consensual e coerente.

Entre os artífices da queda da Monarquia é imperioso que figure Machado Santos. A sua fibra de operacional, de prosélito de um ideal, de conspirador popular e guerreiro astucioso e obstinado em prol da República foi indiscutível. A sua decisão, afinal reflectida, de permanecer e comandar os revoltosos na Praça Marquês de Pombal enquanto outros oficiais debandavam, ajudou

\footnotetext{
${ }^{666}$ ABREU, Jorge de - A Revolução Portuguesa, op. cit., p. 198;

${ }^{667}$ MELO, J. A. Fontes Pereira de - A revolução de 4 de Outubro, op. cit., p. 32.

${ }^{668}$ SILVA, António Maria da - O meu depoimento, op. cit., p. 308.
} 
a compor e projectar a sua legenda de herói. Contudo, foi ele o único "herói da Rotunda" e o "fundador da República", como depois muitos apregoaram? E foram os combates da Rotunda - que originaram do lado dos sublevados, feitas bem as contas, "apenas" dois mortos e 14 feridos $^{669}$ — épicos e plenos de sacrifício, onde os gloriosos amotinados se teriam batido na proporção "de um contra dez", operando desse modo um "milagre"? Não. É preciso depurar a retórica e a memória dos protagonistas dos seus excessos e imprecisões. O discurso historiográfico não serve para criar ou consagrar lendas, nem heróis, nem regimes redentores, mas, ao contrário, para relatar, interpretar o mais objectivamente possível e, portanto, desmistificar a realidade social.

Cumprida a missão que perseguiu obstinadamente desde 1907, Machado Santos transmitiu aos grupos revolucionários ordens, previamente acordadas entre a comissão de resistência e a Maçonaria, que visavam preservar a paz e a ordem cívica em Lisboa e apelavam à união de todos os portugueses em prol da regeneração da pátria ${ }^{670}$. Mais tarde, dirigiu-se em triunfo ao Ministério da Guerra, no Terreiro do Paço, onde foi recebido pelo Presidente do Governo Provisório, Teófilo Braga, que "tão pouco sentira a revolução", o qual terá salientado, num enfadonho discurso, a "intervenção heróica e salvadora do combatente da Rotunda" ${ }^{671}$. Em seguida, regressou para a sua salvífica Rotunda e, só no dia 10, abalou para o quartel de Artilharia 1, de onde regateou, até ao dia 21 de Outubro, do Governo Provisório, com excepcional zelo, as divisas e recompensas dos "bravos" que se bateram ao seu lado sob o seu comando, numa "luta homérica de um contra dez"672.

A partir de então, a aura de herói intrépido começou a desvanecer-se e teceu-se em torno do simples mas presumido comissário naval, entretanto elevado a digníssimo caudilho salvador da pátria, um nebuloso ambiente de intriga que, sem dúvida, alimentou a sua lendária e compulsiva propensão de agitador inquieto. Tal ambiente terá sido exacerbado no rescaldo da revolução,

${ }^{669}$ STEFFANINA, Celestino - Subsídios para a bistória da Revolução..., op. cit., pp. 48-50.

${ }^{670}$ SANTOS, Machado - Relatório, op. cit., pp. 93 e 161.

${ }^{671}$ RELVAS, José - Memórias políticas, op. cit., p. 154.

672 "Relatório de recompensas do comandante Machado Santos aos membros do Governo Provisório da República”. In Relatórios sobre a revolução de 5 de Outubro, op cit., pp.47-53; SANTOS, Machado - Relatório, op. cit., p. 161. 
devido à forma como se intitulou "comandante do Quartel-General da Rotunda" e daí emitiu ordens de promoção de muitos bravos revolucionários à revelia das hierarquias militares ${ }^{633}$; glosou a postura passiva ou ambígua de alguns oficiais e altos membros do P.R.P. durante a conjura, a quem chamou "conspiradores de semicúpios", por se terem refugiado nos Banhos de S. Paulo e não comparecerem na Rotunda ${ }^{674}$; denunciou a atitude dos oficiais que na Rotunda "abandonaram os seus soldados no campo de batalha em frente do inimigo" repreendeu a formação e depois a acção do Governo Provisório; censurou os "adesivos", miraculosamente convertidos aos ideais republicanos; e encarnou, ostensivamente, o papel de guardião moral do espírito imaculado da revolução de Outubro. De resto, a leitura atenta do seu relatório e o estudo do seu posterior comportamento, enquanto parlamentar, director e publicista do jornal O Intransigente (1911-1915), parecem demonstrar o que fica mencionado.

A sua desilusão e consequente desacordo com as opções políticas e o modus operandi seguidos, desde então, pelos principais chefes republicanos foi crescendo, paulatinamente, até ganhar uma tonalidade de intransigência e virulência sistemática com o seu clímax na madrugada de 20 de Outubro de 1921 - quando foi assassinado.

Fim trágico de uma vida cuja leitura compreensiva pode ajudar, e muito, a penetrar nos meandros das frustradas aspirações reformistas da primeira versão do regime republicano em Portugal.

\footnotetext{
${ }^{673}$ Ibidem, op. cit., pp. 160-167.

${ }^{674}$ Ibidem, p. 95.

${ }^{675}$ O Intransigente, 29 de Novembro de 1910.
} 